\section{Field Evaluation of Green and Red Leaf Lettuce Genotypes in the Imperial, San Joaquin, and Salinas Valleys of California for Heat Tolerance and Extension of the Growing Seasons}

\author{
Abbas Lafta \\ U.S. Department of Agriculture (USDA), Agricultural Research Service \\ (ARS), 1636 East Alisal Street, Salinas, CA 93905
}

\author{
Thomas Turini ${ }^{1}$ \\ University of California Cooperative Extension, 1720 South Maple Avenue, \\ Fresno, CA 93702
}

German V. Sandoya

EREC-IFAS, University of Florida, 3200 E Palm Beach Road, Belle Glade, FL 33430

\section{Beiquan Mou' \\ U.S. Department of Agriculture (USDA), Agricultural Research Service (ARS), 1636 East Alisal Street, Salinas, CA 93905}

Additional index words. Lactuca sativa, yield, tipburn, bolting, heat stress, leaf injury, stress tolerance

\begin{abstract}
Global warming poses serious threats and challenges to the production of leafy vegetables. Being a cool-season crop, lettuce is particularly vulnerable to heat stress. To adapt to climate change, this study was conducted to evaluate the performance of leaf lettuce genotypes for heat tolerance by growing them in different locations within California that differ in temperatures during the growing season. Fifteen green leaf and 21 red leaf lettuce genotypes were selected to evaluate their performance under these environments. These genotypes were planted in March and May in Five Points (San Joaquin Valley) and El Centro (Imperial Valley) and in June 2012 in Salinas (Salinas Valley). The results suggest that lettuce planting can be extended from January to March beyond the normal growing seasons in San Joaquin and Imperial Valleys, where yield may be higher than in the Salinas Valley. The further delay in planting date from March to May in Five Points and El Centro resulted in reduction of yield and an increase in susceptibility to bolting and heat-related disorders such as tipburn and leaf desiccation in most genotypes. The susceptibility to these disorders depends on the genotype and the temperature during lettuce growth and maturation. However, heat-tolerant leaf lettuce genotypes adapted to these regions were identified. Results of this research should be useful for the development of heat-tolerant lettuce cultivars and for extending the growing season in warmer but lower land cost areas to reduce production costs.
\end{abstract}

Received for publication 1 Apr. 2016. Accepted for publication 3 Oct. 2016.

The technical assistance of Jeffrey Gunderson, Rafael Solorio, Dave Milligan, and Javier Mora is greatly appreciated. This research was supported by a grant from the California Department of Food and Agriculture Specialty Crop Block Grant Program (SCB10042).

Mention of a trademark, proprietary product, or vendor in this paper should not be construed as a guarantee or warranty of the product by the U.S. Department of Agriculture and does not imply its approval to the exclusion of other products or vendors that also may be suitable. USDA is an equal opportunity provider and employer.

${ }^{1}$ Current address: University of California Cooperative Extension, 550 East Shaw Avenue, Fresno, CA 93710.

${ }^{2}$ Corresponding author.

E-mail: beiquan.mou@ars.usda.gov.
(Barta and Tibbitts, 2000; Thibodeau and Minotti, 1969), and typically develops during rapid plant growth at high temperatures (Cox et al., 1976; Yanagi et al., 1983). Lettuce seed germination is also influenced by high temperature stress (Argyris et al., 2008; Gray, 1975; Kozarewa et al., 2006; Lafta and Mou, 2013; Sung et al., 1998; Thompson et al., 1979). The inhibition of seed germination at high temperatures (thermodormancy) caused a reduction in field emergence, stand establishment, and yield (Cantliffe et al., 1981; Valdes et al., 1985).

Climate change over the next few decades will have profound impacts on agricultural and food systems. The average temperature worldwide is predicted to increase, which may negatively impact the agricultural production and food availability (Karl and Trenberth, 2003; Wurr et al., 1996). Heat tolerance is the ability of plants to grow and perform well under high temperature stress. Development of new crop cultivars that tolerate high temperatures and perform well under warmer and drier climate conditions may mitigate the negative impact of climate change. Breeding and selection for growth, yield, and quality under high temperature stress are important objectives of lettuce breeders working in these environments.

Being a cool-season crop, lettuce is vulnerable to global warming. In this study, we evaluated green and red leaf lettuce germplasm collections for their tolerance to high temperatures to find heat-tolerant genotypes. Field screening for heat tolerance involved growing lettuce germplasm accessions in different environments (different locations) and then comparing the yield and other plant characteristics at these environments to find the best cultivars that perform well under high temperature stress conditions. To ensure year-round supply of products in the United States, most of the lettuce production concentrates in the Salinas Valley, CA, from late spring to early fall, switches to the San Joaquin Valley, CA, in the spring and fall, and shifts to the Imperial Valley, CA, and the Yuma Valley, $\mathrm{AZ}$, in winter. In regions such as the Imperial, San Joaquin, and Yuma Valleys, lettuce is usually planted in the fall or winter (up to January) to allow the crops escape the warmer conditions. Identifying lettuce cultivars that perform well in the field at high temperatures will make it possible to plant lettuce in spring, which in turn will help in expanding the growing season in these warmer areas. Selecting and developing lettuce cultivars suited to these areas will also reduce crop loss and improve the economic opportunity for lettuce producers.

\section{Materials and Methods}

Plant material. Fifteen green leaf cultivars and 21 red leaf lettuce genotypes (20 cultivars and one germplasm accession) were selected through a preliminary screening of more than 1000 genotypes for leaf injury, fresh weight, and survival of seedlings at $43{ }^{\circ} \mathrm{C}$ day $/ 35^{\circ} \mathrm{C}$ night for $12 \mathrm{~h}$ in a growth 
chamber. The putative heat-tolerant genotypes, along with heat-sensitive and commercial cultivar controls, were selected to test their responses to high temperature stress by growing them in different field environments. These genotypes were planted and grown at the University of California (UC) West Side Research and Extension Center in Five Points in the San Joaquin Valley (5 Mar. to 15 May and 8 May to 10 July 2012), UC Desert Research and Extension Center in El Centro in the Imperial Valley (7 Mar. to 9 May and 9 May to 2 July 2012), and USDA-ARS Agricultural Research Station in Salinas (26 June to 20 Aug. 2012) in the Salinas Valley of California. The experiments were arranged in a randomized complete block with four replications per treatment. The experiment units consisted of one row per entry. All plantings were directly seeded in 6-m-long rows with $35 \mathrm{~cm}$ between rows on a 1-m-wide double row-raised bed. Plants were hand thinned to $30 \mathrm{~cm}$ apart in the row about 3 weeks after planting, leaving 20 plants in each plot. The weather data during the growing seasons at the trial sites are shown in Table 1.

At the Five Points site, $168 \mathrm{~kg} \cdot \mathrm{ha}^{-1}$ of monoammonium phosphate $\left(11 \mathrm{~N}-52 \mathrm{P}_{2} \mathrm{O}_{5}-0 \mathrm{~K}\right)$ fertilizer $\left(18.5 \mathrm{~kg} \cdot \mathrm{ha}^{-1}\right.$ of $\mathrm{N}$ and $38.2 \mathrm{~kg} \cdot \mathrm{ha}^{-1}$ of $\mathrm{P})$ was incorporated into the soil preplant; then 112 and $135 \mathrm{~kg} \cdot \mathrm{ha}^{-1}$ of $\mathrm{N}$ as monoammonium phosphate were side dressed into the beds about $40 \mathrm{~d}$ after planting for the March and May plantings, respectively. A postplant preemergence herbicide pronamide (Kerb; Dow AgroSciences, Indianapolis, IN) was applied at $5.8 \mathrm{~L} \cdot \mathrm{ha}^{-1}$. At the El Centro site, $224 \mathrm{~kg} \cdot \mathrm{ha}^{-1}$ of monoammonium phosphate $\left(24.6 \mathrm{~kg} \cdot \mathrm{ha}^{-1}\right.$ of $\left.\mathrm{N}\right)$ fertilizer was incorporated into the beds preplant; then $56 \mathrm{~kg} \cdot \mathrm{ha}^{-1}$ of urea-ammonium nitrate $(32 \mathrm{~N}$, $17.9 \mathrm{~kg} \cdot \mathrm{ha}^{-1}$ of $\mathrm{N}$ ) was applied through irrigation water 16 and $23 \mathrm{~d}$ after planting, respectively, followed by $112 \mathrm{~kg} \cdot \mathrm{ha}^{-1}$ of urea $\left(46 \mathrm{~N}, 51.5 \mathrm{~kg} \cdot \mathrm{ha}^{-1}\right.$ of $\left.\mathrm{N}\right)$ side dressed into the beds 40 and $34 \mathrm{~d}$ after planting, for the March and May plantings, respectively. Pronamide (Kerb) herbicide was applied at $3.4 \mathrm{~kg} \cdot \mathrm{ha}^{-1}$. At the Salinas site, a $6 \mathrm{~N}-20 \mathrm{P}-20 \mathrm{~K}$ fertilizer at $336 \mathrm{~kg} \cdot \mathrm{ha}^{-1}\left(20.2 \mathrm{~kg} \cdot \mathrm{ha}^{-1}\right.$ of N, $67.2 \mathrm{~kg} \cdot \mathrm{ha}^{-1}$ of P, $67.2 \mathrm{~kg} \cdot \mathrm{ha}^{-1}$ of $\mathrm{K}$ ) was applied before field preparation, followed by $336 \mathrm{~kg} \cdot \mathrm{ha}^{-1}$ of ammonium sulfate $\left(21 \mathrm{~N}-24 \mathrm{~S}, 70.6 \mathrm{~kg} \cdot \mathrm{ha}^{-1}\right.$ of $\mathrm{N}, 80.6 \mathrm{~kg} \cdot \mathrm{ha}^{-1}$ of S) side dressed 23 and $38 \mathrm{~d}$ after planting. Postplant preemergence herbicides pronamide (Kerb, $3.5 \mathrm{~L} \cdot \mathrm{ha}^{-1}$ ) and bensulide (Prefar 4-E; Gowan Co., Yuma, $\mathrm{AZ}, 4.7 \mathrm{~L} \cdot \mathrm{ha}^{-1}$ ) were applied. After planting, all plots were irrigated overhead with sprinklers (3-7 times a week till emergence, followed by two times a week till maturity) except the El Centro site where the fields were furrow irrigated once a week following seedling emergence.

At market maturity, five plants were randomly harvested from each plot and evaluated for yield ( $\mathrm{g} /$ plant without roots), plants bolted ( $\%$ of plants with elongated stems), tipburn incidence (number of leaves with brown or black edges/plant), and heat-damaged leaves (number of leaves with areas desiccated from heat stress/plant).

Statistical analysis. Analysis of variance was conducted using the JMP program (SAS Institute Inc., Cary, NC) to determine the effect of environment (E), genotype (G), and the interaction between genotype and environment (GE). Treatment means were separated by the least significant difference at the 0.05 level of probability. The correlation coefficients were determined using the JMP program. The analysis of GGE biplots (Yan and Kang, 2003; Yan et al., 2007) was conducted for the traits measured to show the performance of genotypes among test environments. The analysis was done using GGE biplot software (Yan, 2001). The which-won-where patterns of the GGE biplots visualize the similarities among the environments in discriminating the genotypes. Data for bolted plants, tipburn incidence, and heat-damaged leaves were square root transformed before analysis so that the experimental errors would have a normal distribution.

\section{Results and Discussion}

Green leaf lettuce. There were significant effects of environment, genotype, and the interaction between environment and genotype on yield and percentage of bolted plants (Table 2). Among the green leaf genotypes, cultivar Two Star showed the highest yield followed by Shining Star, Hacienda, Tango, Greengo, and Salad Bowl in March planting at Five Points. Some cultivars, such as Australian Yellow, Green Salad Bowl, Hacienda, Black Seeded Simpson, Grand Rapids, Slobolt, and Coastal Star, showed higher yield in May planting compared with that in March. The percentage increases were $37 \%, 24 \%$, $20 \%, 15 \%, 10 \%, 10 \%$, and $9 \%$, respectively, for each of the cultivars. This suggests that the planting season for some cultivars can be extended from March to May in the San Joaquin Valley.

The yield of green leaf lettuce planted in El Centro in March and May was lower than that at Five Points. This reduction in yield was mainly the effect of high temperatures. The mean temperatures during harvest in July 2012 were 32.8 and $26.1^{\circ} \mathrm{C}$ for El Centro and Five Points, respectively (Table 1). Although other factors such as soil moisture, air humidity, and wind velocity could also affect yield, the experiment fields were well irrigated to ensure adequate soil moisture throughout the growing seasons.

Extending the planting season from March to May in Five Points and El Centro resulted in an increase in percentage of bolted plants in most cultivars tested except Oakleaf and Slobolt (Table 2). Cultivars Salad Bowl, Coastal Star, Green Salad Bowl, and Greengo had a slight increase in bolting. These genotypes showed the lowest bolting incident among the studied cultivars (Table 2), and can therefore be considered the most resistant to bolting across all the environments. 'Hacienda' had the highest yield in May at Five Points, but also showed high susceptibility to bolting.

A higher yield was observed at Five Points than at El Centro or Salinas. This could be due to the prevalence of optimum temperatures for seed germination and early plant growth. The weather conditions at Five Points are considered intermediate between Salinas and El Centro in respect to

Table 1 . Monthly averages of daily maximum, mean, and minimum temperatures $\left({ }^{\circ} \mathrm{C}\right)$, growing degree days $\left(\right.$ base $\left.10^{\circ} \mathrm{C}\right)$, wind velocity $\left(\mathrm{km} \cdot \mathrm{h}^{-1}\right)$, daylength $($ hour minutes), and precipitation ( $\mathrm{cm}$ ) during the field trials in Five Points, El Centro, and Salinas, CA, in 2012.

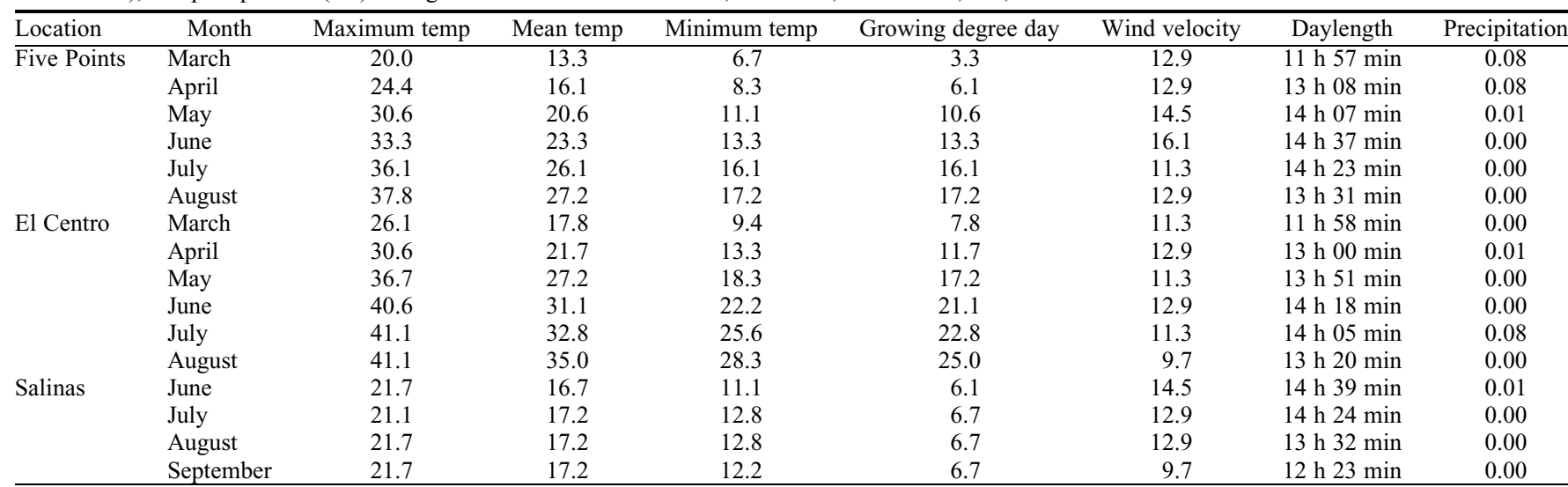

Source: Weather Underground (2016). 
temperatures. May planting showed the highest percentage of bolted plants and this could be due to higher temperatures during plant maturation. 'Tango' showed susceptibility to bolting in Salinas even though the environment was favorable for plant growth and development. Waycott (1995) had demonstrated that high temperatures alone could not promote bolting under short daylength $(8 \mathrm{~h})$. Photoperiods at the trial sites were all longer than $14 \mathrm{~h}$ in June (Table 1). Under such longday conditions, temperature served as the major cause of bolting. Rappaport and Wittwer (1956), using lettuce greenhouse studies, reported that treatments such as vernalizing (low) and high temperatures and long days were additive in decreasing the number of days to bolting and, as the age increased, the influence of high temperatures on bolting became increasingly important.

Tipburn incidence was very low across the environments ( $\leq 1$ leaf per plant) and it was significantly lower for June planting in Salinas and March planting in El Centro (Table 3). PI 278085A showed the highest incidence of tipburn in March planting at Five Points but it showed resistance to this disorder in the other two environments. In May planting at Five Points, cultivars Oakleaf and Australian Yellow showed higher incidence of tipburn than the other cultivars. Cultivars Tango, Shining Star, Coastal Star, and Grand Rapids grown in El Centro with May planting showed increased susceptibility to tipburn incidence. None of the green leaf cultivars showed much tipburn in Salinas and March planting at El Centro.

'Hacienda' showed the highest susceptibility to leaf damage by heat stress in El Centro (Table 3). May planting at El Centro showed the highest percentages of heatdamaged leaves compared with other environments. This indicated that the extension in planting date from March to May resulted in high percentage of leaf damage as a result of increase in temperatures during plant growth and development. The mean daily maximum temperature in El Centro was $41.1{ }^{\circ} \mathrm{C}$ in July 2012 (Table 1).

The codes for the environments and genotypes are shown in Table 4 . There were significant correlation coefficients between environments for each trait of green leaf lettuce (Table 5). There were positive correlations between environments in yield of green leaf lettuce. For the bolting incidence, there were highly positive correlations between Five Points, March planting (P33) and El Centro, March planting (E33) and between Five Points, May planting (P55) and El Centro, May planting (E55). These May environments showed the highest percentage of bolting (Table 2). There was also highly positive correlation between P55 and E33 for tipburn incidence (Table 5). Positive correlation between E33 and E55 existed for

Table 2. Yield and percentage of bolted plants for green leaf lettuce genotypes planted in five different environments.

\begin{tabular}{|c|c|c|c|c|c|c|c|c|c|c|c|c|}
\hline \multirow[b]{3}{*}{ Genotype } & \multicolumn{6}{|c|}{ Yield (g/plant) } & \multicolumn{6}{|c|}{ Plants bolted (\%) } \\
\hline & \multicolumn{2}{|c|}{ Five Points } & \multicolumn{2}{|c|}{ El Centro } & \multirow[b]{2}{*}{ Salinas June } & \multirow[b]{2}{*}{$\operatorname{Mean}(\mathrm{G})$} & \multicolumn{2}{|c|}{ Five Points } & \multicolumn{2}{|c|}{ El Centro } & \multirow[b]{2}{*}{ Salinas June } & \multirow[b]{2}{*}{$\operatorname{Mean}(\mathrm{G})$} \\
\hline & March & May & March & May & & & March & May & March & May & & \\
\hline Australian & 257 & 212 & 114 & 89 & 146 & 164 & 0 & 100 & 0 & 100 & 0 & 40 \\
\hline Australian Yellow & 284 & 390 & 193 & 116 & 198 & 236 & 0 & 67 & 5 & 75 & 0 & 29 \\
\hline Black Seeded Simpson & 396 & 454 & 180 & 145 & 198 & 275 & 0 & 42 & 0 & 100 & 0 & 28 \\
\hline Coastal Star & 248 & 270 & 110 & 96 & 115 & 168 & 0 & 17 & 0 & 0 & 0 & 3 \\
\hline Grand Rapids & 357 & 392 & 137 & 115 & 137 & 228 & 0 & 92 & 0 & 92 & 0 & 37 \\
\hline Green Salad Bowl & 297 & 369 & 154 & 123 & 206 & 230 & 0 & 17 & 0 & 0 & 0 & 3 \\
\hline Greengo & 410 & 139 & 168 & 133 & 99 & 190 & 0 & 17 & 15 & 11 & 0 & 9 \\
\hline Hacienda & 456 & 548 & 141 & 163 & 196 & 301 & 0 & 100 & 0 & 100 & 0 & 40 \\
\hline Oakleaf & 246 & 190 & 139 & 73 & 164 & 162 & 0 & 0 & 0 & 0 & 0 & 0 \\
\hline PI $278085 \mathrm{~A}$ & 383 & 318 & 170 & 139 & 241 & 250 & 15 & 100 & 60 & 100 & 8 & 57 \\
\hline Salad Bowl & 408 & 350 & 197 & 175 & 179 & 262 & 0 & 8 & 0 & 0 & 0 & 2 \\
\hline Shining Star & 480 & 440 & 242 & 151 & 254 & 313 & 0 & 92 & 10 & 67 & 0 & 34 \\
\hline Slobolt & 317 & 350 & 192 & 90 & 214 & 232 & 0 & 0 & 0 & 0 & 0 & 0 \\
\hline Tango & 443 & 280 & 181 & 123 & 199 & 245 & 0 & 100 & 0 & 67 & 25 & 38 \\
\hline Two Star & 567 & 432 & 277 & 167 & 342 & 357 & 0 & 25 & 0 & 0 & 0 & 5 \\
\hline Mean $(E)$ & 370 & 342 & 173 & 127 & 192 & & 1 & 52 & 6 & 47 & 2 & \\
\hline $\mathrm{LSD}_{0.05}$ for $\mathrm{E}^{\mathrm{z}}$ & 41 & & & & & & 8 & & & & & \\
\hline $\mathrm{LSD}_{0.05}$ for $\mathrm{G}$ & 47 & & & & & & 10 & & & & & \\
\hline $\mathrm{LSD}_{0.05}$ for $\mathrm{E} \times \mathrm{G}$ & 105 & & & & & & 22 & & & & & \\
\hline
\end{tabular}

${ }^{\mathrm{z}} \mathrm{E}=$ environment; $\mathrm{G}=$ genotype; $\mathrm{E} \times \mathrm{G}=$ environment $\times$ genotype interaction; $\mathrm{LSD}=$ least significant difference.

Table 3. Incidence of tipburn and heat-damaged leaves for different green leaf lettuce genotypes planted in five environments.

\begin{tabular}{|c|c|c|c|c|c|c|c|c|c|c|c|c|}
\hline \multirow[b]{3}{*}{ Genotype } & \multicolumn{6}{|c|}{ Tipburn (leaves/plant) } & \multicolumn{6}{|c|}{ Heat-damaged leaves (leaves/plant) } \\
\hline & \multicolumn{2}{|c|}{ Five Points } & \multicolumn{2}{|c|}{ El Centro } & \multirow[b]{2}{*}{ Salinas June } & \multirow[b]{2}{*}{ Mean $(G)$} & \multicolumn{2}{|c|}{ Five Points } & \multicolumn{2}{|c|}{ El Centro } & \multirow[b]{2}{*}{ Salinas June } & \multirow[b]{2}{*}{ Mean $(G)$} \\
\hline & March & $\overline{\text { May }}$ & March & $\overline{\text { May }}$ & & & March & $\overline{\text { May }}$ & March & $\overline{\text { May }}$ & & \\
\hline Australian & 0.0 & 0.0 & 0.1 & 0.6 & 0.0 & 0.1 & 0.0 & 0.0 & 0.1 & 5.1 & 0.1 & 1.0 \\
\hline Australian Yellow & 0.0 & 3.2 & 0.0 & 1.6 & 0.6 & 1.1 & 0.0 & 0.3 & 0.1 & 8.6 & 0.3 & 1.8 \\
\hline Black Seeded Simpson & 0.5 & 1.5 & 0.0 & 0.0 & 0.0 & 0.4 & 0.0 & 0.8 & 0.1 & 9.7 & 0.2 & 2.1 \\
\hline Coastal Star & 0.3 & 0.7 & 0.2 & 2.9 & 0.0 & 0.8 & 0.0 & 1.0 & 2.2 & 5.2 & 0.0 & 1.7 \\
\hline Grand Rapids & 2.3 & 0.0 & 0.0 & 2.3 & 0.5 & 1.0 & 0.0 & 1.5 & 0.3 & 9.7 & 0.3 & 2.3 \\
\hline Green Salad Bowl & 0.0 & 0.0 & 0.0 & 0.0 & 0.2 & 0.0 & 0.0 & 0.0 & 0.0 & 2.0 & 0.3 & 0.5 \\
\hline Greengo & 0.6 & 0.0 & 0.0 & 0.3 & 0.2 & 0.2 & 0.0 & 0.5 & 0.1 & 6.7 & 0.0 & 1.5 \\
\hline Hacienda & 0.0 & 0.0 & 0.0 & 0.8 & 0.0 & 0.2 & 0.0 & 0.9 & 7.1 & 17.3 & 0.0 & 5.1 \\
\hline Oakleaf & 2.1 & 6.2 & 0.8 & 1.0 & 0.0 & 2.0 & 0.0 & 0.4 & 1.3 & 6.0 & 0.0 & 1.5 \\
\hline PI 278085 A & 7.6 & 0.3 & 0.0 & 0.0 & 0.0 & 1.6 & 0.0 & 0.0 & 1.1 & 9.3 & 0.0 & 2.1 \\
\hline Salad Bowl & 0.0 & 0.0 & 0.1 & 0.0 & 0.0 & 0.0 & 0.0 & 0.6 & 1.1 & 5.8 & 0.0 & 1.5 \\
\hline Shining Star & 0.0 & 0.0 & 0.1 & 3.7 & 0.0 & 0.8 & 0.0 & 1.3 & 0.8 & 9.6 & 0.0 & 2.3 \\
\hline Slobolt & 0.6 & 0.8 & 0.3 & 1.6 & 0.0 & 0.7 & 0.0 & 0.5 & 2.2 & 4.2 & 0.0 & 1.4 \\
\hline Tango & 0.1 & 0.2 & 0.0 & 5.4 & 0.0 & 1.2 & 0.0 & 0.1 & 0.0 & 5.4 & 0.0 & 1.1 \\
\hline Two Star & 1.0 & 0.0 & 0.0 & 0.0 & 0.0 & 0.2 & 0.0 & 1.8 & 2.6 & 6.7 & 0.0 & 2.2 \\
\hline Mean (E) & 1.0 & 0.9 & 0.1 & 1.3 & 0.1 & & 0.0 & 0.6 & 1.3 & 7.4 & 0.1 & \\
\hline $\mathrm{LSD}_{0.05}$ for $\mathrm{E}^{\mathrm{z}}$ & 0.6 & & & & & & 1.4 & & & & & \\
\hline $\mathrm{LSD}_{0.05}$ for $\mathrm{G}$ & 1.0 & & & & & & 1.2 & & & & & \\
\hline $\mathrm{LSD}_{0.05}$ for $\mathrm{E} \times \mathrm{G}$ & 2.2 & & & & & & 2.6 & & & & & \\
\hline
\end{tabular}

${ }^{\mathrm{z}} \mathrm{E}=$ environment; $\mathrm{G}=$ genotype $\mathrm{E} \times \mathrm{G}=$ environment $\times$ genotype interaction; $\mathrm{LSD}=$ least significant difference. 
heat-damaged leaves, reflecting the similar hot environments. Although not significant, negative correlation between E33 and Salinas, June planting (S66) also existed for heatstress-damaged leaves.

The genotype $\times$ environment interaction of yield, bolting, tipburn, and heat-damaged leaves was analyzed in green leaf lettuce genotypes using the GGE biplot method (Fig. 1). The interactions between genotypes and environments are visualized by the polygon view of the biplot (Yan and Kang, 2003). Two mega environments are indicated based on yield (Fig. 1A). The first mega environment was P55 with 'Hacienda' as the best genotype that showed the highest yield; cultivars such as Black Seeded Simpson, Grand Rapids, and Australian Yellow also performed well in this environment. Although 'Green Salad Bowl' and 'Slobolt' had lower yields, they performed well in this environment. The second mega environment contained E33, E55, P33, and S66, in which 'Two Star' was the best genotype; 'Shining Star' and 'Salad Bowl' also had good performances in these environments. The lowest yielding cultivars were Oakleaf, Australian, Coastal Star, and Greengo (Fig. 1A). Although Hacienda and Two Star were the cultivars with the high yield, they were the least stable according to the Average Environment Coordination (AEC) plot shown in Fig. 1A. In the same figure, cultivars Black Seeded Simpson and Shining Star were high producers with good stability. The most representative environments were the planting in El Centro in May and the planting in Salinas in June.

The GGE biplot for the susceptibility to bolting is graphed in Fig. 1B. E55 with 'Australian', 'Australian Yellow', 'Hacienda', 'Grand Rapids', and 'Tango' had the most

Table 4. Codes of green and red leaf lettuce genotypes and environments (locations).

\begin{tabular}{llll}
\hline \multicolumn{1}{c}{ Green leaf lettuce } & & \multicolumn{1}{c}{ Red leaf lettuce } \\
\hline Genotype name & Code & & Genotype name \\
\hline Australian & Aus & Battalion & Code \\
Australian Yellow & Auy & Big Red & Brd \\
Black Seeded Simpson & Bls & Eruption & Eru \\
Coastal Star & Cos & Hyper Red Rumple Waved & Hrr \\
Grand Rapids & Grr & Ibis & Ibs \\
Green Salad Bowl & Gsb & Lolla Rossa & Llr \\
Greengo & Gre & Mariachi AMR & Mar \\
Hacienda & Hac & Marimba & Mrm \\
Oakleaf & Oak & Merlot & Mer \\
PI 278085 A & P85 & Prizehead & Prz \\
Salad Bowl & Sad & Red Dog & Rdd \\
Shining Star & Shi & Red Embers & Rde \\
Slobolt & Slo & Red Flower & Rdf \\
Tango & Tan & Red Fox & Rox \\
Two Star & Two & Red Prize & Rdp \\
Environments (locations) & & Red Rage & Rdr \\
Five Points-March planting & P33 & Red Rebosa & Rro \\
Five Points-May planting & P55 & Red Sails & Rsa \\
El Centro-March planting & E33 & Red Tide & Ret \\
El Centro-May planting & E55 & Revolution & Rev \\
Salinas-June planting & S66 & Sunglow & Sun \\
\hline
\end{tabular}

Table 5. Correlation coefficients between environments and traits for green and red leaf lettuce genotypes.

\begin{tabular}{|c|c|c|c|c|c|c|c|c|}
\hline \multirow[b]{2}{*}{ Environment } & \multicolumn{4}{|c|}{ Green leaf lettuce } & \multicolumn{4}{|c|}{ Red leaf lettuce } \\
\hline & P33 & P55 & E33 & E55 & P33 & P55 & E33 & E55 \\
\hline & \multicolumn{4}{|c|}{ Yield } & \multicolumn{4}{|c|}{ Yield } \\
\hline P55 & 0.49 & & & & $0.91 * *$ & & & \\
\hline E33 & $0.74 * *$ & 0.39 & & & $0.90 * *$ & $0.91 * *$ & & \\
\hline E55 & $0.83 * *$ & $0.60 *$ & $0.59 *$ & & $0.77 * *$ & $0.73 * *$ & $0.80 * *$ & \\
\hline S66 & $0.63^{*}$ & $0.57 *$ & $0.81^{* *}$ & 0.48 & $0.81 * *$ & $0.77 * *$ & $0.80 * *$ & $0.65 * *$ \\
\hline & \multicolumn{4}{|c|}{ Bolting } & \multicolumn{4}{|c|}{ Bolting } \\
\hline P55 & 0.32 & & & & 0.00 & & & \\
\hline E33 & $0.96 * *$ & 0.31 & & & 0.00 & 0.01 & & \\
\hline E55 & 0.32 & $0.89 * *$ & 0.29 & & 0.00 & $0.84 * *$ & 0.18 & \\
\hline S66 & 0.24 & 0.41 & 0.19 & 0.21 & 0.00 & 0.00 & 0.00 & 0.00 \\
\hline & \multicolumn{4}{|c|}{ Tipburn } & \multicolumn{4}{|c|}{ Tipburn } \\
\hline P55 & 0.08 & & & & $0.79 * *$ & & & \\
\hline E33 & 0.05 & $0.78 * *$ & & & -0.10 & -0.15 & & \\
\hline E55 & -0.23 & -0.04 & 0.03 & & $0.89 * *$ & $0.78 * *$ & -0.13 & \\
\hline S66 & -0.04 & 0.13 & -0.27 & 0.03 & 0.19 & 0.19 & -0.15 & 0.29 \\
\hline & \multicolumn{4}{|c|}{ Heat-damaged leaves } & \multicolumn{4}{|c|}{ Heat-damaged leaves } \\
\hline P55 & 0.00 & & & & 0.00 & & & \\
\hline E33 & 0.00 & 0.33 & & & 0.00 & $0.58 * *$ & & \\
\hline E55 & 0.00 & 0.36 & $0.62 *$ & & 0.00 & $0.65 * *$ & $0.55^{*}$ & \\
\hline$\underline{\text { S66 }}$ & 0.00 & -0.08 & -0.42 & -0.06 & 0.00 & 0.12 & -0.17 & -0.06 \\
\hline
\end{tabular}

$*, * *$ Represent significant correlations at $5 \%$ and $1 \%$ levels of probability, respectively. susceptible genotypes to bolting. PI $278085 \mathrm{~A}$ was the susceptible genotype to bolting in the mega environment that contained S66, P33, E33, and P55; cultivars Shining Star and Greengo also had a high proportion of bolted plants. The most resistant cultivars to bolting were Oakleaf, Slobolt, Salad Bowl, Green Salad Bowl, Coastal Star, and Two Star; these cultivars are grouped together in the GGE biplot (Fig. 1B). PI 278085A had the highest percentage of bolted plants (Table 2); this genotype was also the most stable for this trait, meaning that this genotype generated bolted plants in all the studied environments. Other cultivars such as Hacienda, Grand Rapids, Tango, Black Seeded Simpson, and Australian Yellow also presented high levels of bolted plants that were environment-dependent (Fig. 2B). According to the AEC figure, the two most stable environments were P33 and S66, because the two environments had the least number of bolted plants overall (Fig. 2B)

PI 278085A was the most susceptible genotype to tipburn in the P33 environment; 'Two Star', 'Grand Rapids', and 'Black Seeded Simpson' also had higher number of leaves with tipburn per plant (Fig. 1C). However, in the P55 environment, the most susceptible cultivar to tipburn was Oakleaf followed by Australian Yellow; both cultivars also showed tipburn in E33 or S66 (Fig. 1C). The tolerant cultivars to tipburn were Green Salad Bowl, Salad Bowl, Australian, Hacienda, and Greengo (Fig. $1 \mathrm{C}$; Table 3). Although PI 278085A was the genotype with the highest number of leaves with tipburn in P33, it was not the most stable for tipburn across these environments. 'Oakleaf' was highly susceptible across different environments (Fig. 2C). E55 was the environment with consistently high number of leaves with tipburn; on the other hand E33 and S66 had the least presence of leaves with tipburn (Fig. 2C).

The highest susceptibility to heat-damaged leaves was observed in 'Hacienda' in the mega environment that constituted E55, E33, and P55 (Fig. 1D), followed by 'Shining Star', PI 278085A, and 'Two Star'. The most tolerant cultivars to heat-damaged leaf were Green Salad Bowl, Australian, and Tango (Fig. 1D; Table 3). The genotype with more leaf damage was 'Hacienda', but 'Two Star', 'Shining Star', 'Grand Rapids', and PI 278085A had more consistency across the environments (Fig. 1D).

Cultivars Two Star, Hacienda, and Shining Star showed the highest yields. Among these three cultivars, Shining Star was the most stable genotype across different environments in terms of yield under heat stress. However 'Shining Star' had high percentage of plants bolted as a consequence of heat stress. This indicated that this cultivar is not recommended for high-temperature regions. A more suitable cultivar for these regions would be Two Star (Two). Even though this cultivar was not the most stable genotype across different environments, its average yield and low percentage of bolted plants, along with a low number of leaves with 

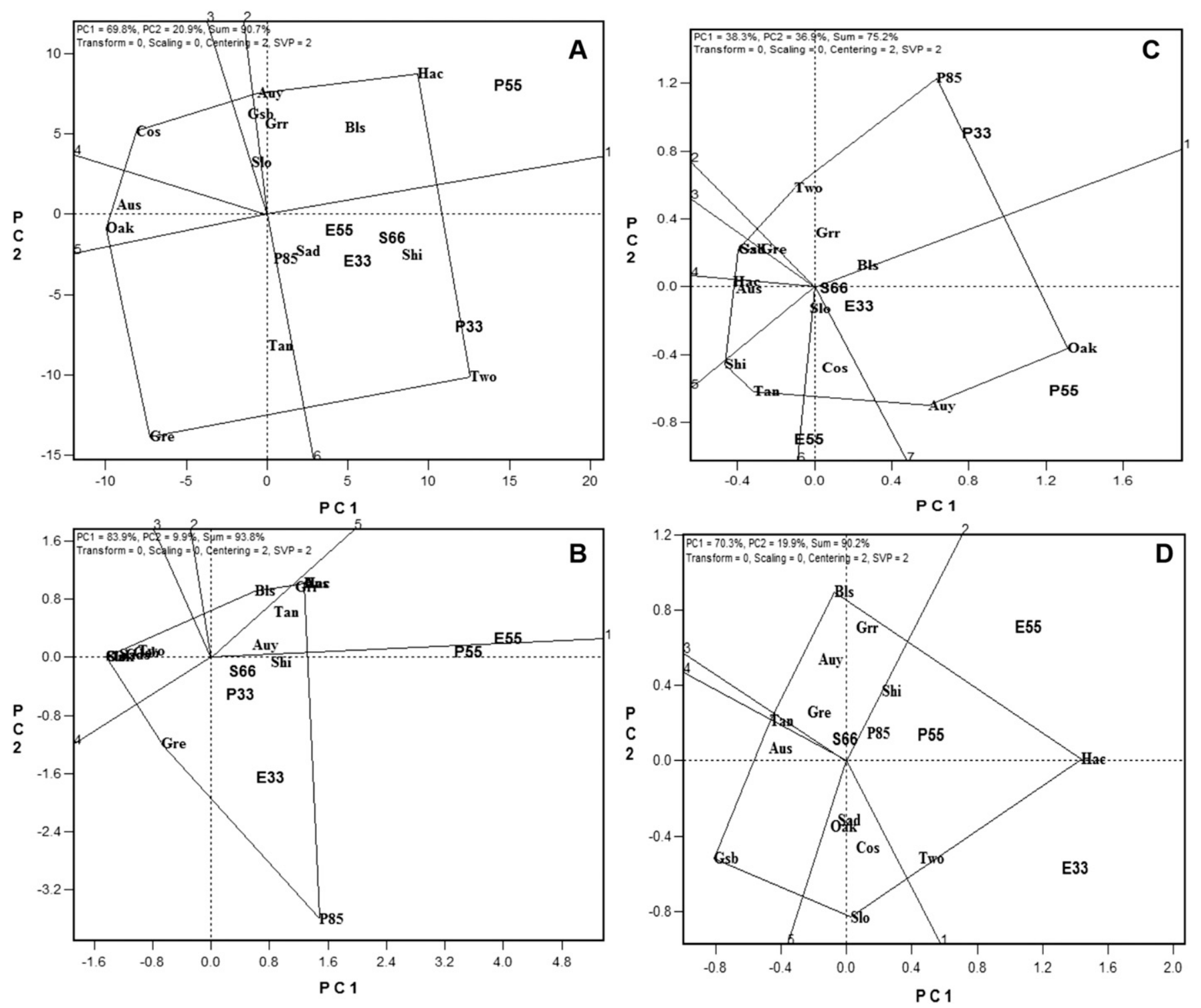

Fig. 1. Which-won-where view of the GGE biplot showing the performance of green leaf lettuce genotypes in terms of the (A) highest yield and (B) highest susceptibility to bolting, (C) tipburn, and (D) heat-damaged leaves. Principal components PC1 and PC2 explained $69.8 \%$ and $20.9 \%$ of the variation for yield; $83.9 \%$ and $9.9 \%$ for bolting; $38.3 \%$ and $36.9 \%$ for tipburn; and $70.3 \%$ and $19.9 \%$ for heat-damaged leaves.

tipburn, make it a better choice for the hot areas. 'Hacienda' showed the high yield, but it was also more susceptible to bolting and heat-damaged leaves and therefore this cultivar cannot be recommended for hightemperature regions.

Red leaf lettuce. The effects of environment, cultivar, and the interaction between environment and cultivar on red leaf lettuce yield and percentage of bolted plants are shown in Table 6. March planting at Five Points resulted in significantly higher yield than other locations. The lowest yield was observed in May planting at El Centro. This region is associated with high temperatures during the growing season. The results indicated that delaying the planting time from March to May reduced lettuce yield. This reduction in yield was mainly due to an increase in temperatures. The highest yield at Five Points in March planting was observed for the following cultivars: Red Rage,
Red Dog, Big Red, Red Sails, Red Fox, Red Tide, and Sunglow (Table 6). However in May planting at Five Points, the highest yield was observed for the following cultivars: Red Fox, Red Dog, Red Tide, Prizehead, Red Prize, and Red Rage. Cultivars Battalion, Merlot, and Revolution showed the lowest yield at Five Points in both March and May plantings. At El Centro, cultivars Red Tide, Red Sails, Red Dog, Big Red, Red Rage, and Red Fox showed the highest yield in March planting. However in May planting, all cultivars showed a reduction in yield. The highest yield in Salinas was observed for cultivars Big Red, Red Dog, Red Tide, and Red Sails.

There was not much bolting and generally no significant differences in percentage of bolted plants between cultivars in Salinas and March plantings in Five Points and El Centro (Table 6). However, the extension of planting from March to May resulted in significant differences in percentage of bolted plants between cultivars. The highest incidence of bolting in May planting at Five Points was observed in cultivars Red Dog, Red Rage, Red Flower, Big Red, and Hyper Red Rumple. At El Centro for the same period, the highest incidence of bolting was observed in cultivars Red Dog, Red Flower, Sunglow, Big Red, Red Tide, and Hyper Red Rumple. The significant increase in bolting during May planting in both Five Points and El Centro was related to high temperatures.

There was no significant difference in tipburn incidence between cultivars in March plantings at Five Points and El Centro and Salinas except for 'Sunglow' that showed the highest incidence of tipburn (Table 7). However in May plantings, there were significant differences in tipburn incidence among cultivars. The highest incidence of tipburn in May planting at Five Points was observed in cultivars Red Flower, Sunglow, Prizehead, Red Fox, and Red Rage, in that order. At El 

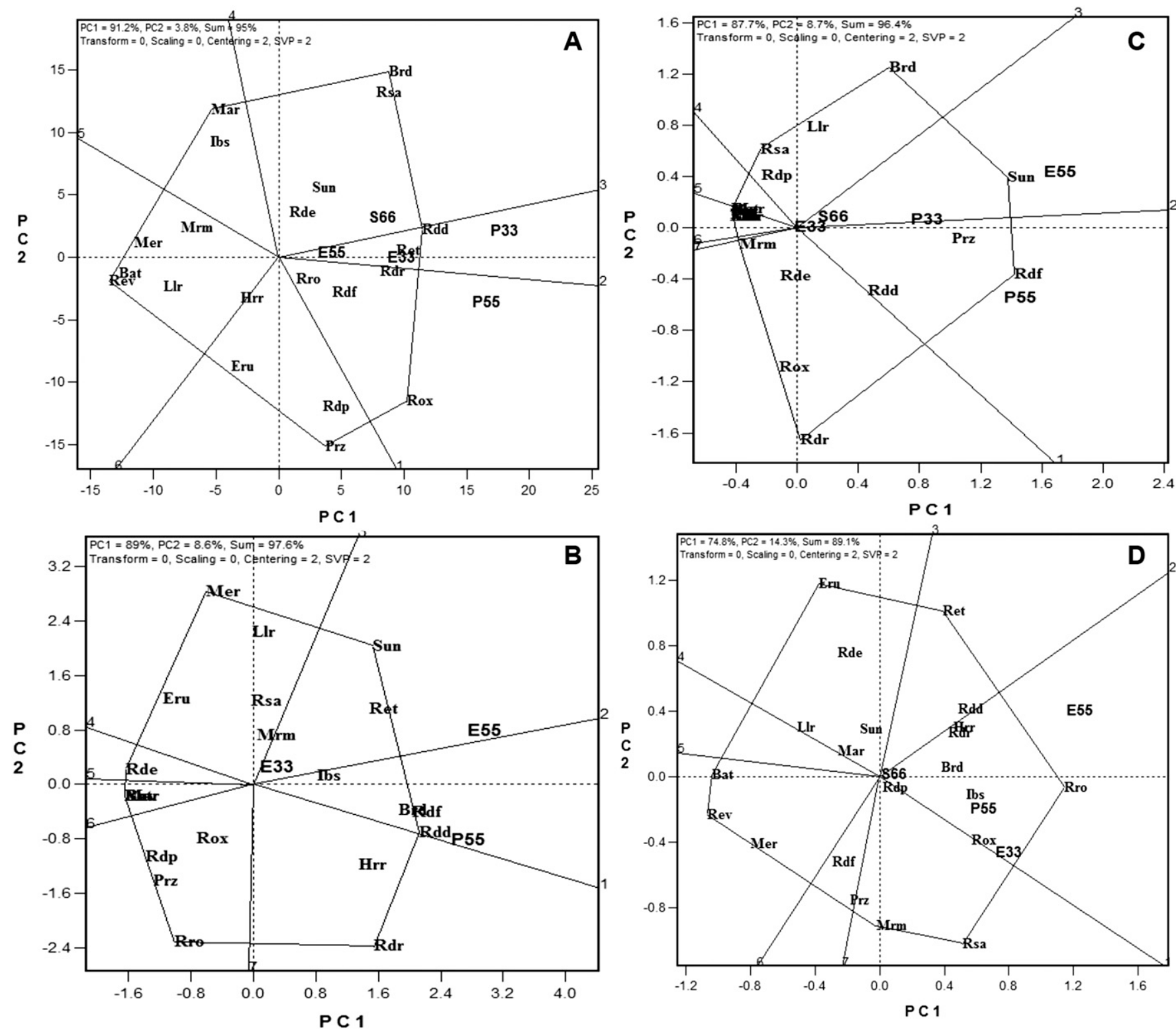

Fig. 2. Which-won-where view of the GGE biplot showing the performance of red leaf lettuce genotypes in terms of the (A) highest yield and (B) highest susceptibility to bolting, (C) tipburn, and (D) heat-damaged leaves. Principal components PC1 and PC2 explained $91.2 \%$ and $3.8 \%$ of the variation for yield; $89 \%$ and $8.6 \%$ for bolting; $87.7 \%$ and $8.7 \%$ for tipburn; and $74.8 \%$ and $14.3 \%$ for heat-damaged leaves.

Centro, the highest incidence of tipburn in May planting was observed in cultivars Sunglow, Red Flower, Prizehead, Big Red, and Lolla Rossa, in the mentioned order. The most susceptible cultivars to tipburn across the environments were Red Flower, Sunglow, Prizehead, Big Red, and Red Fox.

There were no significant differences in number of heat-damaged leaves between cultivars planted in March at Five Points or Salinas (Table 7). However for plantings in May at Five Points and in March and May at El Centro, there were significant differences in heat-damaged leaves among cultivars. At Five Points, the highest incidence of heatdamaged leaves was observed in 'Red Rebosa'. At El Centro in March planting, the highest incidence of heat-damaged leaves was observed in cultivars Red Rebosa, Red Sails, Marimba, Red Fox, and Ibis, in that order. In May planting at El Centro, a high number of heat-damaged leaves were observed in cultivars Red Rebosa, Red Tide, Hyper Red Rumple, Red Rage, Red Dog, and Ibis. The most resistant cultivars to heatdamaged leaves across the environments were Revolution, Battalion, Merlot, and Lolla Rosa. These cultivars were also associated with low yield (Table 6).

There were positive correlations between environments on yield of red leaf lettuce (Table 5). There was positive correlation between P55 and E55 on percentage of bolted plants. Positive correlation on tipburn incidence also existed between P55 and P33, E55 and P33, and E55 and P55. Positive correlations on heat-damaged leaves existed between E33 and P55, E55 and P55, and E55 and E33. E55, E33, and P55 were considered as the warmer environments. This suggests that bolting and damaged leaves were associated with high temperature stress.
The genotype $\times$ environment interaction of red leaf lettuce genotypes in relation to highest yield and the susceptibility to bolting, tipburn, and heat-damaged leaves was analyzed using the GGE biplot method (Fig. 2). Based on plant yield, the best cultivar in the S66 environment was Big Red; cultivars such as Red Sails, Sunglow, and Red Embers also performed as good producers. The mega environment that contained P33, E33, and E55 had Red Dog as the best cultivar that showed the highest yield; Red Tide was also seen to be a good cultivar in those environments (Fig. 2A). The highest yielding cultivar in P55 environment was Red Fox followed by Red Rage, Red Flower, and Red Rebosa. The lowest yielding cultivars were Merlot, Battalion, Revolution, Lolla Rossa, and Marimba (Fig. 2A). Cultivars Sunglow, Red Rebosa, and Red Rage were the most yield-stable across different environments. The planting 
Table 6. Yield and percentage of bolted plants for red leaf lettuce genotypes grown in five environments.

\begin{tabular}{|c|c|c|c|c|c|c|c|c|c|c|c|c|}
\hline \multirow[b]{3}{*}{ Genotype } & \multicolumn{6}{|c|}{ Yield (g/plant) } & \multicolumn{6}{|c|}{ Plant bolted (\%) } \\
\hline & \multicolumn{2}{|c|}{ Five Points } & \multicolumn{2}{|c|}{ El Centro } & \multirow[b]{2}{*}{ Salinas June } & \multirow[b]{2}{*}{ Mean (G) } & \multicolumn{2}{|c|}{ Five Points } & \multicolumn{2}{|c|}{ El Centro } & \multirow[b]{2}{*}{ Salinas June } & \multirow[b]{2}{*}{ Mean $(G)$} \\
\hline & March & May & March & $\overline{\text { May }}$ & & & March & May & March & May & & \\
\hline Battalion & 130 & 54 & 24 & 23 & 62 & 59 & 0 & 0 & 0 & 0 & 0 & 0 \\
\hline Big Red & 495 & 338 & 227 & 101 & 298 & 292 & 0 & 83 & 0 & 92 & 0 & 35 \\
\hline Eruption & 221 & 219 & 157 & 91 & 128 & 163 & 0 & 0 & 0 & 25 & 0 & 5 \\
\hline Hyper Red Rumple & 273 & 220 & 106 & 81 & 144 & 165 & 0 & 75 & 0 & 75 & 0 & 30 \\
\hline Ibis & 261 & 138 & 83 & 56 & 165 & 141 & 0 & 50 & 0 & 67 & 0 & 23 \\
\hline Lolla Rossa & 145 & 111 & 118 & 41 & 109 & 105 & 0 & 17 & 0 & 58 & 0 & 15 \\
\hline Mariachi AMR & 233 & 139 & 103 & 51 & 210 & 147 & 0 & 0 & 0 & 0 & 0 & 0 \\
\hline Marimba & 189 & 125 & 89 & 39 & 139 & 116 & 0 & 25 & 0 & 42 & 0 & 13 \\
\hline Merlot & 115 & 81 & 46 & 30 & 124 & 79 & 0 & 0 & 0 & 38 & 0 & 8 \\
\hline Prizehead & 357 & 364 & 192 & 94 & 155 & 232 & 0 & 17 & 0 & 0 & 0 & 3 \\
\hline Red Dog & 504 & 436 & 228 & 137 & 295 & 320 & 0 & 100 & 0 & 100 & 0 & 40 \\
\hline Red Embers & 350 & 258 & 140 & 63 & 201 & 203 & 0 & 0 & 20 & 0 & 0 & 4 \\
\hline Red Flower & 367 & 343 & 188 & 75 & 234 & 241 & 0 & 92 & 0 & 100 & 0 & 38 \\
\hline Red Fox & 475 & 468 & 211 & 72 & 236 & 292 & 0 & 17 & 0 & 17 & 0 & 7 \\
\hline Red Prize & 353 & 354 & 195 & 58 & 177 & 227 & 0 & 8 & 0 & 0 & 0 & 2 \\
\hline Red Rage & 526 & 353 & 214 & 83 & 156 & 266 & 0 & 100 & 0 & 67 & 0 & 33 \\
\hline Red Rebosa & 339 & 268 & 196 & 111 & 170 & 217 & 0 & 25 & 0 & 0 & 0 & 5 \\
\hline Red Sails & 483 & 311 & 262 & 92 & 262 & 282 & 0 & 17 & 0 & 44 & 0 & 12 \\
\hline Red Tide & 437 & 403 & 278 & 107 & 288 & 303 & 0 & 50 & 5 & 92 & 0 & 29 \\
\hline Revolution & 90 & 48 & 41 & 32 & 74 & 57 & 0 & 0 & 0 & 0 & 0 & 0 \\
\hline Sunglow & 403 & 254 & 184 & 130 & 175 & 229 & 0 & 58 & 30 & 100 & 0 & 38 \\
\hline Mean (E) & 321 & 252 & 156 & 75 & 181 & & 0 & 35 & 3 & 44 & 0 & \\
\hline $\mathrm{LSD}_{0.05}$ for $\mathrm{E}^{\mathrm{z}}$ & 8 & & & & & & 4 & & & & & \\
\hline $\mathrm{LSD}_{0.05}$ for $\mathrm{G}$ & 37 & & & & & & 11 & & & & & \\
\hline $\mathrm{LSD}_{0.05}$ for $\mathrm{E} \times \mathrm{G}$ & 82 & & & & & & 25 & & & & & \\
\hline
\end{tabular}

${ }^{\mathrm{z}} \mathrm{E}=$ environment; $\mathrm{G}=$ genotype; $\mathrm{E} \times \mathrm{G}=$ environment $\times$ genotype interaction.

Table 7. Tipburn incidence and heat-stress-damaged leaves for different red leaf lettuce genotypes grown in five environments.

\begin{tabular}{|c|c|c|c|c|c|c|c|c|c|c|c|c|}
\hline \multirow[b]{3}{*}{ Genotype } & \multicolumn{6}{|c|}{ Tipburn (leaves/plant) } & \multicolumn{6}{|c|}{ Heat-damaged leaves (leaves/plant) } \\
\hline & \multicolumn{2}{|c|}{ Five Points } & \multicolumn{2}{|c|}{ El Centro } & \multirow[b]{2}{*}{ Salinas June } & \multirow[b]{2}{*}{ Mean $(G)$} & \multicolumn{2}{|c|}{ Five Points } & \multicolumn{2}{|c|}{ El Centro } & \multirow[b]{2}{*}{ Salinas June } & \multirow[b]{2}{*}{ Mean $(\mathrm{G})$} \\
\hline & March & $\overline{\text { May }}$ & March & $\overline{\text { May }}$ & & & March & $\overline{\text { May }}$ & March & $\overline{\text { May }}$ & & \\
\hline Battalion & 0.0 & 0.0 & 0.0 & 0.0 & 0.0 & 0.0 & 0.0 & 0.0 & 0.0 & 1.1 & 0.2 & 0.3 \\
\hline Big Red & 0.9 & 1.4 & 0.0 & 5.1 & 1.5 & 1.8 & 0.0 & 1.0 & 1.3 & 6.3 & 0.4 & 1.8 \\
\hline Eruption & 0.0 & 0.0 & 0.3 & 0.0 & 0.0 & 0.1 & 0.0 & 0.0 & 0.0 & 4.4 & 0.0 & 0.9 \\
\hline Hyper Red Rumple & 0.0 & 0.0 & 0.0 & 0.0 & 0.3 & 0.1 & 0.0 & 0.6 & 1.2 & 7.8 & 0.0 & 1.9 \\
\hline Ibis & 0.0 & 0.0 & 0.0 & 0.0 & 0.3 & 0.1 & 0.0 & 0.6 & 1.9 & 7.0 & 0.0 & 1.9 \\
\hline Lolla Rossa & 0.0 & 0.5 & 0.0 & 3.3 & 0.0 & 0.8 & 0.0 & 0.4 & 0.2 & 2.5 & 0.0 & 0.6 \\
\hline Mariachi AMR & 0.0 & 0.0 & 0.0 & 0.0 & 0.3 & 0.1 & 0.0 & 0.3 & 0.5 & 3.7 & 0.0 & 0.9 \\
\hline Marimba & 0.0 & 0.2 & 0.0 & 0.0 & 0.0 & 0.0 & 0.0 & 0.2 & 2.4 & 3.4 & 0.0 & 1.2 \\
\hline Merlot & 0.0 & 0.0 & 0.0 & 0.0 & 0.0 & 0.0 & 0.0 & 0.1 & 0.4 & 1.2 & 0.0 & 0.3 \\
\hline Prizehead & 1.0 & 6.0 & 0.0 & 7.6 & 0.3 & 3.0 & 0.0 & 0.7 & 0.9 & 2.3 & 0.2 & 0.8 \\
\hline Red Dog & 0.5 & 4.0 & 0.0 & 2.4 & 0.4 & 1.5 & 0.0 & 1.3 & 1.0 & 7.4 & 0.3 & 2.0 \\
\hline Red Embers & 0.0 & 1.0 & 0.0 & 0.3 & 0.0 & 0.3 & 0.0 & 0.5 & 0.1 & 4.2 & 0.2 & 1.0 \\
\hline Red Flower & 2.5 & 8.9 & 0.0 & 8.3 & 0.1 & 4.0 & 0.0 & 0.6 & 1.3 & 2.9 & 0.3 & 1.0 \\
\hline Red Fox & 0.0 & 5.2 & 0.0 & 0.0 & 0.7 & 1.2 & 0.0 & 0.8 & 2.4 & 6.8 & 0.1 & 2.0 \\
\hline Red Prize & 0.0 & 0.1 & 0.0 & 0.5 & 0.2 & 0.2 & 0.0 & 0.9 & 0.4 & 4.1 & 0.7 & 1.2 \\
\hline Red Rage & 0.1 & 3.8 & 0.0 & 0.0 & 0.0 & 0.8 & 0.0 & 1.6 & 0.8 & 7.4 & 0.0 & 1.9 \\
\hline Red Rebosa & 0.0 & 0.0 & 0.0 & 0.0 & 0.0 & 0.0 & 0.0 & 2.4 & 2.6 & 10.8 & 0.0 & 3.2 \\
\hline Red Sails & 0.0 & 0.0 & 0.0 & 0.8 & 0.0 & 0.2 & 0.0 & 1.5 & 2.6 & 4.8 & 0.0 & 1.8 \\
\hline Red Tide & 0.0 & 0.0 & 0.0 & 0.0 & 0.3 & 0.1 & 0.0 & 0.1 & 1.0 & 8.6 & 0.1 & 1.9 \\
\hline Revolution & 0.0 & 0.0 & 0.0 & 0.0 & 0.0 & 0.0 & 0.0 & 0.0 & 0.1 & 0.8 & 0.0 & 0.2 \\
\hline Sunglow & 3.5 & 6.8 & 0.0 & 8.6 & 0.3 & 3.8 & 0.0 & 0.2 & 0.5 & 4.3 & 0.0 & 1.0 \\
\hline Mean (E) & 0.4 & 1.8 & 0.0 & 1.8 & 0.2 & & 0.0 & 0.6 & 1.0 & 4.8 & 0.1 & \\
\hline $\mathrm{LSD}_{0.05}$ for $\mathrm{E}^{\mathrm{z}}$ & 0.8 & & & & & & 0.9 & & & & & \\
\hline $\mathrm{LSD}_{0.05}$ for $\mathrm{G}$ & 1.2 & & & & & & 0.7 & & & & & \\
\hline $\mathrm{LSD}_{0.05}$ for $\mathrm{E} \times \mathrm{G}$ & 2.7 & & & & & & 1.6 & & & & & \\
\hline
\end{tabular}

${ }^{\mathrm{z}} \mathrm{E}=$ environment; $\mathrm{G}=$ genotype; $\mathrm{E} \times \mathrm{G}=$ environment $\times$ genotype interaction.

in May in El Centro gave maximum stability across cultivars as well (Fig. 2A).

The most susceptible cultivar to bolting in E55 and E33 environments was Sunglow followed by Red Tide (Fig. 2B). However in P55 environment, Red Dog was seen to be the most susceptible cultivar to bolting, followed by Red Flower, Big Red, and Ibis. The other two environments (P33 and S66) had no bolted plants and hence they are not graphed in the biplot. Cultivars Battalion,
Mariachi AMR, and Revolution showed no bolting in any of the plantings (Table 6).

Sunglow was the most sensitive cultivar to tipburn in the mega environment that constituted E55, P33, and S66. However in the P55 environment, Red Flower was the most susceptible cultivar to tipburn, followed by Prizehead and Red Dog (Fig. 2C). Prizehead was also the most stable cultivar across different environments followed by Red Dog, and E33 was the representative environment (Fig. 2C).
Susceptibility to heat-damaged leaves was observed in Red Rebosa in association with the mega environment that contained E55, P55, E33, and S66 (Fig. 2D). Further, cultivars such as Red Fox, Ibis, Big Red, Hyper Red Rumple, and Red Rage had a considerable amount of heat-damaged leaves in those environments. The most tolerant cultivars to heat-damaged leaves were Battalion, Revolution, and Merlot. Several cultivars had consistent levels of such leaf damage across the 
Table 8. Correlation coefficients between traits for green and red leaf lettuce genotypes.

\begin{tabular}{|c|c|c|c|c|c|c|}
\hline \multirow[b]{2}{*}{ Trait } & \multicolumn{3}{|c|}{ Green leaf lettuce } & \multicolumn{3}{|c|}{ Red leaf lettuce } \\
\hline & Yield & Tipburn & $\begin{array}{c}\text { Heat-stressed } \\
\text { leaves }\end{array}$ & Yield & Tipburn & $\begin{array}{c}\text { Heat-stressed } \\
\text { leaves }\end{array}$ \\
\hline & \multicolumn{3}{|c|}{ E33 } & \multicolumn{3}{|c|}{ E33 } \\
\hline Tipburn & -0.02 & & & -0.01 & & \\
\hline Heat-stressed leaves & -0.04 & -0.05 & & 0.11 & -0.09 & \\
\hline Bolting & 0.14 & -0.12 & -0.04 & 0.02 & -0.02 & -0.07 \\
\hline & \multicolumn{3}{|c|}{ E55 } & \multicolumn{3}{|c|}{ E55 } \\
\hline Tipburn & $-0.26^{*}$ & & & $0.36^{* *}$ & & \\
\hline Heat-stressed leaves & $0.48 * *$ & $-0.26^{*}$ & & $0.49 * *$ & -0.13 & \\
\hline Bolting & 0.01 & 0.03 & $0.49 * *$ & $0.37 * *$ & $0.27 *$ & $0.31 * *$ \\
\hline & \multicolumn{3}{|c|}{ P33 } & \multicolumn{3}{|c|}{ P33 } \\
\hline Tipburn & $0.26^{*}$ & & & $0.24 *$ & & \\
\hline Heat-stressed leaves & 0.00 & 0.00 & & 0.00 & 0.00 & \\
\hline \multirow[t]{2}{*}{ Bolting } & 0.15 & $0.72^{* *}$ & 0.00 & 0.00 & 0.00 & 0.00 \\
\hline & \multicolumn{3}{|c|}{ P55 } & \multicolumn{3}{|c|}{ P55 } \\
\hline Tipburn & -0.22 & & & $0.43^{* *}$ & & \\
\hline Heat-stressed leaves & $0.42 * *$ & -0.15 & & $0.31 * *$ & 0.01 & \\
\hline \multirow[t]{2}{*}{ Bolting } & $0.27 *$ & $-0.25^{*}$ & 0.05 & $0.50^{* *}$ & $0.29 * *$ & $0.27^{*}$ \\
\hline & \multicolumn{3}{|c|}{ S66 } & \multicolumn{3}{|c|}{ S66 } \\
\hline Tipburn & -0.01 & & & $0.22 *$ & & \\
\hline Heat-stressed leaves & 0.17 & $0.81 * *$ & & 0.11 & $0.36^{* *}$ & \\
\hline \multirow[t]{2}{*}{ Bolting } & 0.21 & -0.04 & -0.05 & 0.00 & 0.00 & 0.00 \\
\hline & \multicolumn{3}{|c|}{ All environments } & \multicolumn{3}{|c|}{ All environments } \\
\hline Tipburn & 0.03 & & & 0.16 & & \\
\hline Heat-stressed leaves & $-0.27 * *$ & 0.02 & & $-0.29 * *$ & 0.09 & \\
\hline Bolting & 0.06 & 0.07 & $0.43 * *$ & 0.00 & $0.37 * *$ & $0.45 * *$ \\
\hline
\end{tabular}

studied environments. Such cultivars included Red Fox, Red Prize, Ibis, and Big Red (Fig. 2D).

Under extremely hot environment (May planting in El Centro), unlike green leaf cultivars, all red leaf cultivars had lower yield than in the Salinas planting (Tables 2 and 6). However, there were not many differences in bolting, tipburn, and heatdamaged leaves between green and red leaf lettuces (Tables 2, 3, 6, and 7).

The symptom of the heat-damaged leaf was taken as the desiccation of the part of the leaf that started from the leaf tip and progressed toward the middle of the leaf with no discoloration associated with this disorder. Most of the damaged leaves occurred in the center of the plants or between the over-matured leaves and the apex of the plant. On the other hand, tipburn is a physiological disorder that appears as necrotic areas along the margin of the leaves. This disorder is associated with calcium deficiency in the affected leaf areas and typically occurs during rapid growth at high temperatures (Barta and Tibbitts, 2000; Cox et al., 1976; Thibodeau and Minotti, 1969; Yanagi et al., 1983).

When all environments are considered, leaf damages caused by heat stress were negatively correlated to yield for both red and green leaf lettuce genotypes (Table 8). Heat-damaged leaves were also associated with bolting. These correlations were especially significant in warmer environments like E55 and P55, where there were more heat-stress-damaged leaves (Table 8). Tipburn leaves were associated with bolting only for red leaf lettuce, especially in the warmer E55 and P55 locations. The results indicated that the reduction in yield and the development of most of the physiological disorders in lettuce are associated with high temperatures as previously reported (Glenn, 1984; Jenni, 2005; Jenni and Yan, 2009; Ryder, 1999). There were significant variations in the susceptibility of lettuce genotypes to these physiological disorders and this susceptibility was also influenced by the interaction between the genotype and the environment (Jenni and Yan, 2009).

Global warming and climate change pose serious challenges to California's agriculture and place unprecedented pressures on the sustainability of horticulture industry. California's "Salad Bowl"-Salinas Valley, could turn into a dust bowl by the end of the century, as global warming takes its toll. Adapting the leafy greens industry to future conditions is essential to meet the needs of a growing population and the increasing deshow that global warming over the next several decades will take place irrespective of any action taken today. Thus the development of crops that can cope with heat, drought, and other climate extremes may well be the single most important step we can take to adapt to the changing environment. However, breeding a new cultivar takes time, often about 10 years. Our ability to breed these new cultivars is undermined by the rapid loss of the genetic diversity of plants, which is in turn accelerated by climate changes. Therefore, there is an urgent need to mitigate the abiotic stresses through improvement of leafy vegetables for future environments. The heat-tolerant leaf lettuce genotypes identified in this study may help the development of commercial cultivars adapted to a warming planet.

In addition, leafy vegetables are losing acreage to housing and industrial development mand for leafy vegetable products. Forecasts as well as competition from other crops such as strawberry. Further, land cost in the major production areas of Salinas Valley of coastal California is very high. Land value in the Salinas Valley is two to four times of the land value in the inland San Joaquin and Imperial Valleys (Campbell, 2007). Identification of heat-tolerant genotypes can help to expand the growing seasons of lettuce in hot but low land cost areas such as Central Valley or Imperial Valley. It may expand lettuce production seasons from the current 4 months in San Joaquin, Yuma, and Imperial Valleys to 9 months. As the costs of land, labor, fuel, fertilizer, packing material, food safety, and transportation continue to rise, it is essential to reduce production costs of leafy vegetables. Expanding production in warmer regions may reduce land costs and improve the sustainability and profitability of U.S. lettuce crops. Results of this research suggest that the latest planting date for most leaf lettuce cultivars can be safely extended from the current January to March in the San Joaquin and Imperial Valleys, where many of these cultivars even had higher yield than in the Salinas Valley (Tables 2 and 6). However, planting leaf lettuce in the inland valleys in May needs the use of heat-tolerant cultivars. For example, cultivars Eruption, Red Embers, and Slobolt performed well when planted in Five Point in the San Joaquin Valley in both March and May (Tables 2, 3, 6, and 7). 'Greengo' and 'Salad Bowl' had similar or higher yield from March and May plantings in El Centro compared with June planting in Salinas, although they developed heat-damaged leaves when planted in May (Tables 2 and $3)$. Another potential limiting factor is irrigation water, as the San Joaquin Valley has been facing water shortage due to the historic drought in recent years. However, planting a short-duration and high-value crop like lettuce provides more flexibility in water management as compared with a perennial crop like almond that occupies much of the acreage in San Joaquin Valley at present. Heat-tolerant lettuce genotypes also tend to be drought tolerant, as they may share similar stress tolerance mechanisms (Mou, unpublished data).

In conclusion, the results of this study suggest that leaf lettuce planting can be extended from January to March with an acceptable yield in the San Joaquin and Imperial Valleys, where land costs are lower than in the Salinas Valley. For most cultivars, the further delay in planting date from March to May in Five Points and El Centro resulted in reduction of yield and an increase in bolting and susceptibility to stress-related disorders such as tipburn and leaf desiccation due to high temperatures during lettuce growth and maturation. However, some heat-tolerant cultivars suitable for these hot environments were identified. Year-round lettuce production in these valleys may need the careful selection of cultivars or breeding work to increase the level of heat tolerance. The heattolerant genotypes identified in this study may aid in such breeding effort. 


\section{Literature Cited}

Argyris, J., P. Dahal, E. Hayashi, D.W. Still, and K. J. Bradford. 2008. Genetic variation for lettuce seed thermoinhibition is associated with temperature-sensitive expression of abscisic acid, gibberellin, and ethylene biosynthesis, metabolism, and response genes. Plant Physiol. 148:926-947.

Barta, D.J. and T.W. Tibbitts. 2000. Calcium localization and tipburn development in lettuce leaves during early enlargement. J. Amer. Soc. Hort. Sci. 125:294-298.

Campbell, K. 2007. Agricultural land values increase. AgAlert, 2 May 2007. 18 Dec. 2015. $<$ http://www.agalert.com/story/?id=813>.

Cantliffe, D.J., K.D. Shuler, and A.C. Guedes. 1981. Overcoming seed thermodormancy in a heat-sensitive romaine lettuce by seed priming. HortScience 16:196-198.

Cox, E.F., J.M.T. McKee, and A.S. Dearman. 1976. The effect of growth rate on tipburn occurrence in lettuce. J. Hort. Sci. 51:297-309.

Glenn, E.P. 1984. Seasonal effect of radiation and temperature on growth of greenhouse lettuce in a high insolation desert environment. Sci. Hort. 22:9-21.

Gray, D. 1975. Effect of temperature on the germination and emergence of lettuce (Lactuca sativa) varieties. J. Hort. Sci. 50:349-361.

Jenni, S. 2005. Rib discoloration: A physiological disorder induced by heat stress in crisphead lettuce. HortScience 40:2031-2035.
Jenni, S. and W. Yan. 2009. Genotype by environment interactions of heat stress disorder resistance in crisphead lettuce. Plant Breed. 128:374-380.

Karl, T.R. and K.E. Trenberth. 2003. Modern global climate change. Science 302:17191723.

Kozarewa, I., D.J. Cantliffe, R.T. Nagata, and P.J. Stoffella. 2006. High maturation temperature of lettuce seeds during development increased ethylene production and germination at elevated temperatures. J. Amer. Soc. Hort. Sci. 131:564-570.

Lafta, A. and B. Mou. 2013. Evaluation of lettuce genotypes for seed thermotolerance. HortScience 48:708-714.

Rappaport, L. and S.H. Wittwer. 1956. Flowering in head lettuce as influenced by seed vernalization, temperature, and photoperiod. J. Amer. Soc. Hort. Sci. 67:429-437.

Ryder, E.J. 1999. Lettuce, endive and chicory. CAB Intl., New York, NY.

Sung, Y., D.J. Cantliffe, and R.T. Nagata. 1998. Seed developmental temperature regulation of thermotolerance in lettuce. J. Amer. Soc. Hort. Sci. 123:700-705.

Thibodeau, P.O. and P.L. Minotti. 1969. The influence of calcium on the development of lettuce tipburn. J. Amer. Soc. Hort. Sci. 94: 372376.

Thompson, P.A., S.A. Cox, and R.H. Sanderson. 1979. Characterization of the germination responses to temperature of lettuce (Lactuca sativa L.) achenes. Ann. Bot. (Lond.) 43:319334.

Valdes, V.M., K.J. Bradford, and K.S. Mayberry. 1985. Alleviation of thermodormancy in coated lettuce seeds by seed priming. HortScience 20:1112-1114.

Waycott, W. 1995. Photoperiodic response of genetically diverse lettuce accessions. J. Amer. Soc. Hort. Sci. 120:460-467.

Weather Underground. 2016. Weather history. 18 May 2016. <https://www.wunderground.com/ history>.

Wurr, D.C.E., J.R. Fellows, and K. Phelps. 1996. Investigating trends in vegetable crop response to increasing temperature associated with climate change. Sci. Hort. 66:255-263.

Yan, W. 2001. GGE biplot: A windows application for graphical analysis of multi-environment trial data and other types of two-way data. Agron. J. 93:1111-1118.

Yan, W. and M.S. Kang. 2003. GGE biplot analysis: A graphical tool for breeders, geneticists, and agronomists. CRC Press, Boca Raton, FL.

Yan, W., M.S. Kang, B. Ma, S. Woods, and P.L. Cornelius. 2007. GGE biplot vs. AMMI analysis of genotype-by-environment data. Crop Sci. 47:643-655.

Yanagi, A.A., R.M. Bullock, and J.J. Cho. 1983. Factors involved in the development of tipburn in crisphead lettuce in Hawaii. J. Amer. Soc. Hort. Sci. 108:234-237. 